○特集 $\mid$ フィルム・シート技術の最新技術

\title{
体内でのフィルム形成一腹膜癒着防止膜と薬物送達膜一
}

\author{
伊藤大知 1,2$) *$ ・鈴木幸光 2 ) \\ 1）東京大学大学院医学系研究科 疾患生命工学センター％ 113-0033 東京都文京区本郷 7-3-1 \\ 2）東京大学大学院工学系研究科 化学システム工学専攻 ₹ 113-0033 東京都文京区本郷 7-3-1
}

\section{Formation of a Biocompatible Film in vivo -from Peritoneal Adhesion to Drug Delivery System-}

\section{Taichi Ito ${ }^{1,2) *}$ and Yukimitsu Suzuki ${ }^{2)}$}

1) Center for Disease Biology and Integrative Medicine Faculty of Medicine, The University of Tokyo 7-3-1 Hongo, Bunkyo-ku, Tokyo 113-0033, Japan

2) Department of Chemical System Engineering, The University of Tokyo 7-3-1 Hongo, Bunkyo-ku, Tokyo 113-0033, Japan

Postoperative peritoneal adhesions cause pelvic pain, infertility, and potentially lethal bowel obstruction. We have designed and synthesized injectable hydrogels that are formed by mixing hydrazide-modified hyaluronic acid (HA) with aldehyde-modified versions of cellulose derivatives such as carboxymethylcellulose (CMC), hydroxypropylmethyl cellulose (HPMC), and methyl cellulose (MC). Hydrogels degraded in the presence of hyaluronidase in vitro, with HA-MC and HA-HPMC degrading more slowly than HAX and HA-CMC. All the cellulose-derived gels showed efficacy in reducing the area of adhesion formation in a rabbit sidewall defect-bowel abrasion model. In addition, we have designed and synthesized an injectable hydrogel composed of cross-linkable modified hyaluronic acids conjugated to dexamethasone, and investigated its anti-inflammatory function. The hydrogel degraded in media over 5 days, releasing dexamethasone slowly over that time preventing TNF- $\alpha$ production from lipopolysaccharide-stimulated primary mousice macrophages in vitro. Further research is on-going. We are designing cisplatin releasing system based on this in-situ crosslinkable hydrogel system for treating peritoneal dissemination.

Key words : membrane / hydrogel / in situ crosslinking / biomaterial / drug delivery / peritoneal adhesion / peritoneal dissemination

\section{1.はじめに}

「膜」は無限の可能性を秘めている．膜分離技術 は環境技術の切り札の一つであるし, 燃料電池の電 解質膜はシステムの中のコア技術の一つである. エ レクトロニクスにおけるシリコン薄膜や，バイオ燃

* Corresponding Author

Tel: 03-5841-1696

Fax: 03-5841-1697

E-mail: taichi@m.u-tokyo.ac.jp
料電池やバイオセンサーで使われるメディエーター 薄膜も電子伝達を担う膜ということで包含される. またバイオテック分野でも, 酵素固定膜型反応器, 医療用透析膜, バイオフィルム形成など様々な分野 において「膜」を考えねばならない。もうひとつの 雄, 生体膜でも細胞レベルで細胞膜は, 細胞内外を 区切るだけでなく，流動性と安定性を両立すること によって, 細胞内外を区画する膜としての役割だけ でなく, そこでは膜タンパク質が物質透過制御, シ グナル伝達, 酵素反応など様々な役割を担っている. さらに生体組織は驚くほどに膜状組織が多く, 細胞 


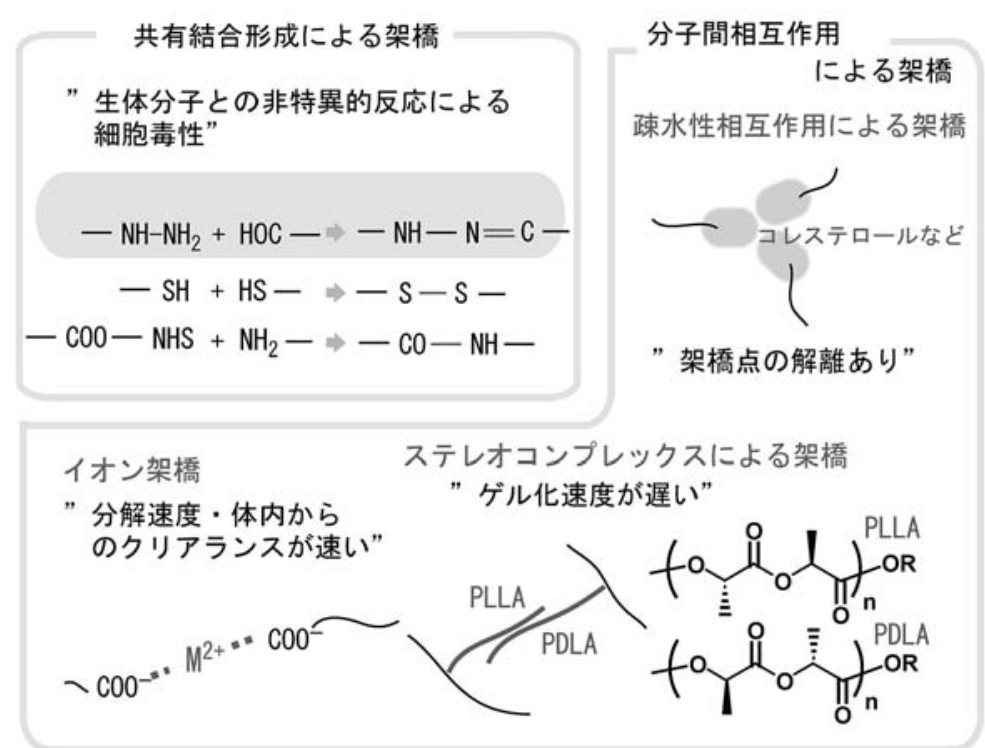

特徵が様々であり、用途に応じて様々な架橋様式が提案、

用いられている

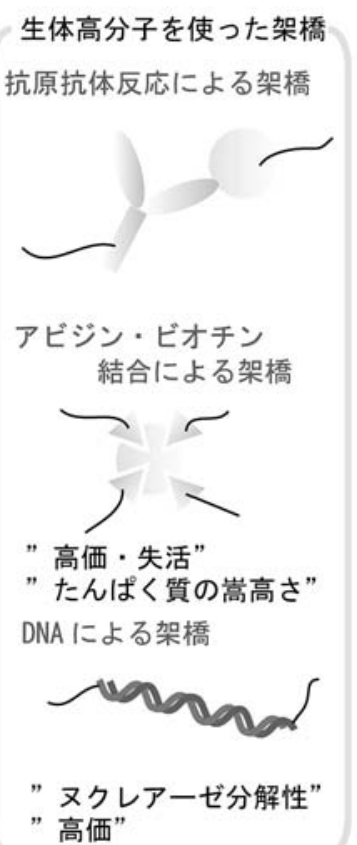

Fig. 1 Various crosslinking reactions for in situ crosslinkable hydrogels.

が単層に集積して形成した細胞単層膜が，さらに集 積して組織や臟器が形成されていると言っても過言 ではない.

煎じつめれば，「膜」とは 2 次元平面状に無限に広 げることが可能でありながら，その厚みは数 $\mathrm{nm}$ から 数 $100 \mu \mathrm{m}$ 程度の厚みに限定される材料でかつ, その 内部（時には表面も）で厚さ方向に対して物質移動 や化学反応がおこるダイナミックな空間である, と 位置付けられよう。だからこそ様々な研究や技術の 展開が将来展望できると思われる，今回はこのよう な大枠の中で捉え, 生体適合性に優れたハイドロゲ 儿薄膜について報告する. とりわけ体外ではプレカ 一サー水溶液でありながら, 混合しながら体内に注 入すると同時に，体内でハイドロゲル薄膜化する医 用材料について報告する.

\section{2. in situ架橋ハイドロゲル}

ハイドロゲルは，3次元高分子ネットワーク中に豊 富に水を含有した物質である. SDS-pageに用いられ るのはポリアクリルアミドゲルであり，アガロース 電気泳動ゲルも，ハイドロゲルである。これらハイ ドロゲルの中でも, 生体適合性に優れた多糖類を基 盤としたハイドロゲルは，再生医療の細胞増殖足場 （スキャフォールド）材料や，薬物送達担体などとし て, 医療応用が期待され, 実際に様々な臨床分野で 適用となっている。

中でも体外では水溶液でありながら, 生体内に注 入すると同時にハイドロゲルとなる『in situ架橋ハ イドロゲル』は様々な用途が期待される. (1)カテー テルやリザーバー・ポートを通して体外から, 望み の疾患部位に注入することができる.このため近年 増加している内視鏡技術との相性が非常に良い. (2) 皮下注射などにより容易に体内浅部にハイドロゲル を形成できる。 (3)細胞やタンパク質製剤の封入が容 易である利点から, 再生医療やドラッグデリバリー システム（DDS）への応用が可能である.これら体 内環境下でゲル化する材料としては物理架橋ゲルと 化学反応架橋ゲルがある (Fig. 1).

例えばポリプロピレンオキサイドとポレエチレン グリコールのトリブロック共重合体（例えば Pluronic F127：独・BASF社）は ${ }^{1)}$ 低温でゾル状態であり, 高温でゲル化する．ポリマー濃度を制御することに よって相転移温度 (LCST) をシフトさせることがで き, 生体適合性もある程度優れる。このため室温で は溶液状態であり, 体内に注入して体温化ではハイ ドロゲルとなる．このような温度応答型のゲルとし ては, ポリリン酸エステルポリマー2,3) なども近年報 告されている.

イオン架橋も古くから用いられており， $\beta-\mathrm{D}-$ マ ンヌロン酸と $\alpha-\mathrm{L}-$ グルロン酸の 2 種のブロックが結 合した直線状の多糖類であるアルギン酸 ${ }^{4)}$ は, カル シウムイオン存在下で, エッグポケットと呼ばれる 独特の架橋点を形成し, 速やかにゲル化する. 体内 のカルシウムイオン濃度は低いために血中濃度では ゲル化しないが, 細胞封入担体などとして良く検討 


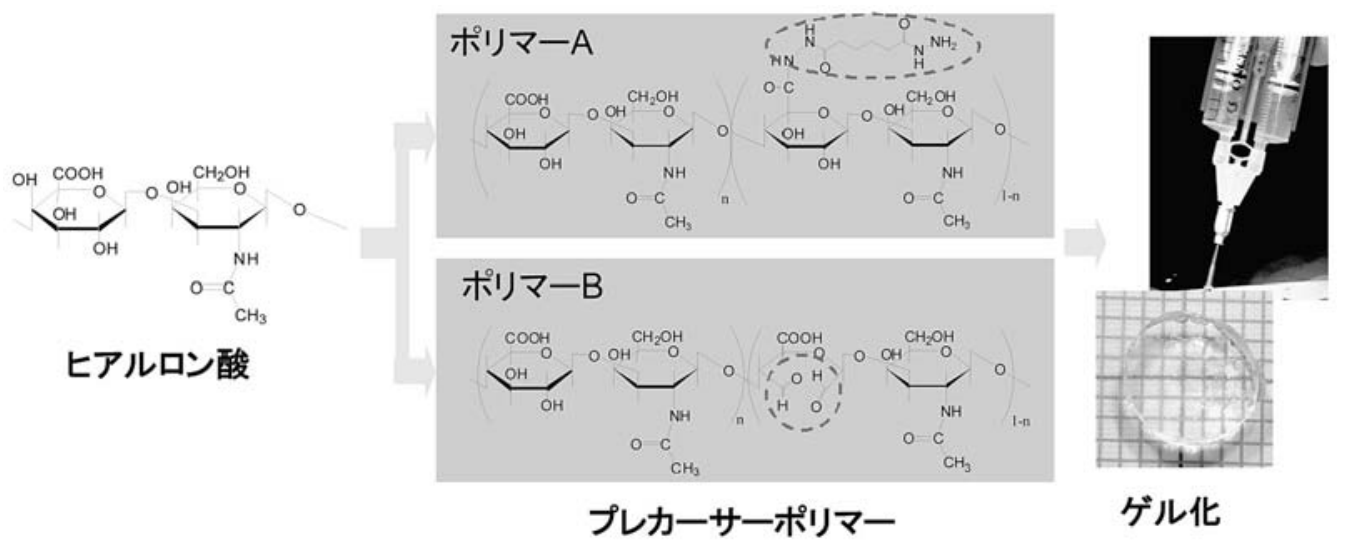

Fig. 2 in situ crosslinkable hydrogel based on hyaluronic acid.

されている.

化学反応架橋ゲルは最も良く用いられているin $s i t u$ 架橋様式である. 天然物ではフィブリン糊などは 臨床で用いられている。血液から抽出したフィブリ ノーゲン (A液) とトロンビン（酵素，B液）を（テ イシール : 米・バクスター社5)）ダブルシリンジで混 合しながら患部に注入することによって，組織接着 剂として広範囲に用いられてきた。工学的に言えば, 生体組織間での in situ接着性薄膜の迅速形成である. またカルボジイミドやチオール結合形成 ${ }^{6}$ )の化学反 応を利用することによって，in situ架橋ゲルを作製 する試みも多くなされてきた.

主な in situ架橋様式を Fig. 1にまとめた。様々な物 理架橋, 化学架橋の様々な方法が利用, あるいは期 待されていることがわかる. DNAの二重らせん形成 によるハイドロゲル形成などは，DNAの電気伝導性 への期待などと相まって，ボトムアップ型ナノテク ノロジーとして近年注目を集めているところである. 本研究では特に，ヒドラドゾン結合形成を利用した 多糖類 in situ架橋ゲル ${ }^{7)}$ の開発と, その腹膜癒着防 止応用について報告する。

\section{3. 腹膜癒着を抑制するin situ架橋ハイドロ ゲルの開発}

\section{1 腹膜癒着とは?}

胃・腸・肝臓・膵臓など多くの臓器を含む腹腔内 臓器の開腹手術や腹腔鏡手術後に, 臓器同士，ある いは腹腔を包む腹膜と臓器がしばしば癒着し剥れな くなる。これを腹膜癒着という ${ }^{8)}$. 癒着は大腸の通過 障害, 不妊, 慢性骨盤痛などを引き起こし, 癒着が 重篤の場合は，腸の通過障害などにより緊急の 2 次 手術を要する場合もある。何よりも再手術を行う際 に，まず癒着をメスで切り離すプロセスが必要とな
り，これが執刀医泣かせである.

腹膜癒着プロセスは, (1)手術等による腹腔内の腹 膜あるいは臓器漿膜の中皮細胞層破壊, (2)急性炎症 反応の開始, (3)同時に血液凝固系の活性化によるフ イブリンの形成, (4)繊維芽細胞の浸潤, (5)癒着の形 成, と進む。癒着は創傷治癒プロセスと表裏一体で あり, 癒着形成の前に, フィブリンが溶解して, 中 皮細胞層が回復すれば，癒着形成を防ぐことができ ると考えられている.

\section{2 腹膜癒着防止材料と in situ 架橋ハイドロ ゲル}

この癒着を抑制する材料として, Seprafilm ${ }^{\circledR}$ (米

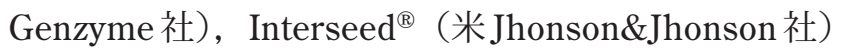
などの癒着防止フィルム ${ }^{8)}$ が上市されている。これ は物理的に臓器同士の接触を防ぐことで癒着防止を 行うが, 癒着が起こる場所をあらかじめ予測するこ とが不可能なこと, 腹腔鏡で使用不可能なことなど から, 新しい材料が期待されている.

我々はフィルム状材料に代わる癒着防止材料とし て, 2 種の多糖類プリカーサーポリマー溶液（アルデ ヒド基修飾多糖類とヒドラジド基修飾多糖類）を，2 液混合シリンジを通して混合注入するだけで, 腹腔 内で速やかにゲル化するin situ架橋ハイドロゲルを 開発した（Fig. 2） 9)。プレカーサーポリマー中のア ルデヒド基とヒドラジド基が, 速やかにハイドゾン 結合を形成して架橋し腹膜や漿膜を広範囲に覆うこ とができる.

\section{3 in situ 架橋ハイドロゲルの材料設計}

プレカーサーポリマー原料である多糖類としては, 腹腔内で生体適合性に優れる, ヒアルロン酸 (HA), カルボキシメチルセルロース (CMC), メチルセル ロース（MC），ヒドロキシプロピルセルロース 
Table 1 Physical properties of cross-linked hydrogels

\begin{tabular}{lccc}
\hline & $\begin{array}{c}\text { Gelation time } \\
(\mathrm{sec})\end{array}$ & $\begin{array}{c}\text { Swelling ratio* } \\
(\%)\end{array}$ & $\begin{array}{c}\mathrm{G}^{*} \\
(\mathrm{~Pa})\end{array}$ \\
HAX & $3.5 \pm 1.0$ & $200 \pm 14$ & $32 \pm 17$ \\
HA-CMC & $19.0 \pm 1.7$ & $230 \pm 10$ & $92 \pm 19$ \\
HA-HPMC & $4.0 \pm 1.2$ & $120 \pm 13$ & $292 \pm 109$ \\
HA-MC & $5.8 \pm 2.9$ & $150 \pm 4$ & $297 \pm 41$ \\
\hline
\end{tabular}

* Measured on day 5 of immersion in phosphate buffered saline

Date are averages \pm standard deviations $(\mathrm{n}=4)$

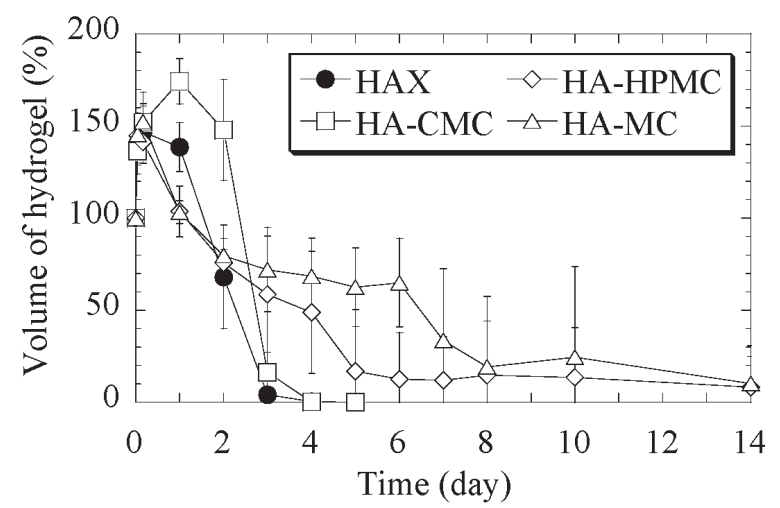

Fig. 3 Degradation kinetics of the hydrogels in $10 \mathrm{unit} / \mathrm{ml}$ hyaluronidase in PBS at $37^{\circ} \mathrm{C}$. Volume of the hydrogel (\%) is the ratio of the volume of hydrogel at each time point to the initial volume, expressed as a percentage. Data are averages \pm standard deviations $(n=4)$.

（HPMC）などのセルロース誘導体 ${ }^{10)}$ ，デキストラ ン11)などが用いられる。 またプルランやデキストリ ンなどの他の多糖類や，ポリエチレングリコールな ども腹腔内で使用実績がある．選択したポリマーの 物性や官能基修飾度は，得られるハイドロゲルの架 橋度などのゲルの構造とともに，ハイドロゲルの力 学特性, 膨潤度, 分解特性を左右し, 最終的に癒着 抑制特性を左右する.

Table 1 はヒドラジド基修飾 HA とアルデヒド基修 飾 HAが in situ架橋したゲル（HAX），及びヒドラジ ド基修飾 $\mathrm{HA}$ とアルデヒド基修飾 $\mathrm{CMC}, \mathrm{MC}$, HPMC が in situ架橋したゲル HA-CMC, HA-MC, HA-HPMCのゲル化時間, 膨潤度（初期のゲル体積 とリン酸バッファー下膨潤平衡時のゲル体積の比), レオメーターにより測定した剛性率を示している. 荷電の有無やポリマー骨格のフレキシビリティなど の用いられた多糖類の物性と, 架橋度の違いなどに よって, 様々な物性のゲルが得られることがわかる.

さらにヒアルロン酸分解酵素下で各ハイドロゲル の分解実験を行ったところ, 剛性率が高い HA-MC, HA-HPMC で分解速度が遅く, 剛性率が低い HAX, HA-CMCで早いことが示された（Fig. 3).

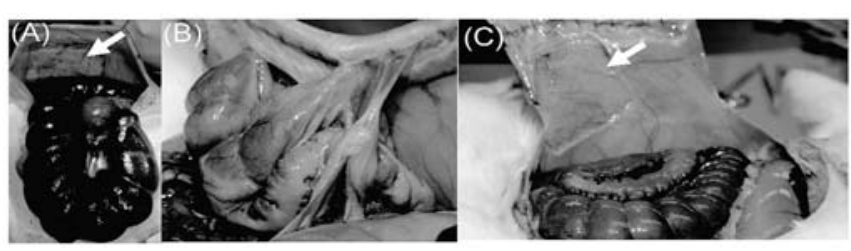

Fig. 4 Prevention of peritoneal adhesions in a rabbit abrasion model. (A). Induction of adhesions. Note the abdominal wall defect (arrow), and the bleeding surface of the cecum. (B). Adhesions seen on dissection after 1 week in an animal treated with saline. (C). Absence of adhesions after 1 week in an animal treated with HA-MC.

Table 2 Effectiveness of hydrogels in preventing peritoneal adhesions in the rabbit

\begin{tabular}{lcccc}
\hline & $\begin{array}{c}\text { HA } \\
\text {-CMC }\end{array}$ & $\begin{array}{c}\text { HA } \\
\text {-HPMC }\end{array}$ & $\begin{array}{c}\text { HA } \\
\text {-MC }\end{array}$ & $\begin{array}{c}\text { Control } \\
\text { (生理食塩水) }\end{array}$ \\
\hline $\begin{array}{l}\text { Animal weight loss } \\
\text { postoperatively (\%) }\end{array}$ & $6.5 \pm 3.6$ & $2.8 \pm 2.6$ & $8.4 \pm 3.3$ & $11.7 \pm 2.4$ \\
\hline Score 3 & 1 & 2 & 0 & 3 \\
Score 2 & 1 & 0 & 0 & 1 \\
Score 1 & 0 & 0 & 1 & 0 \\
No adhesion & 2 & 2 & 3 & 0 \\
\hline Median score & $\mathbf{1}$ & $\mathbf{2}$ & $\mathbf{0}$ & $\mathbf{3}$ \\
\hline Adhesion area $\left(\mathbf{c m}^{2}\right)$ & $\mathbf{2 . 2} \pm \mathbf{3 . 3}$ & $\mathbf{0 . 3} \pm \mathbf{0 . 6}$ & $\mathbf{0 . 0} \pm \mathbf{0 . 0}$ & $\mathbf{1 3 . 1} \pm \mathbf{1 . 9}$ \\
\hline
\end{tabular}

\section{4 in situ 架橋ハイドロゲルの癒着抑制効果}

このような特徴を有するハイドロゲルの腹膜癒着 抑制効果を，実際にウサギを用いた動物モデルによ つて実証することに成功した ${ }^{9 \sim 11}$. 開腹後, 腹膜の 一部を $3 \times 4 \mathrm{~cm}$ で切除し, 腹膜に対応する盲腸の一 部を出血させることによって, 1 週間後に再開腹して 確認すると確実に癒着を起こすことができる (Fig. 4).このモデルに閉腹前に in situ架橋ハイドロ ゲルを適用し, 1 週間後に再開腹して, 癒着重度をス コアリングし, 癒着面積を計測することで, 材料の 癒着抑制機能を検証することができる（Table 2). HAX, HA-CMC, HA-MC, HA-HPMCの各 in situ 架橋ハイドロゲルのうち, HA-MCが最大の癒着抑制 機能を示した。材料物性と癒着防止効果の相関はこ れからの検討課題である.

\section{4. デキサメタゾン徐放in situ架橋ハイドロ ゲルの開発}

ハイドロゲル薄膜のみでは, 癒着低減効果には限 界があり DDSの応用が期待される．初期炎症反応は, 様々な生物学的カスケードを経て, t-PA（ティッシ ユプラスミノーゲンーアクティベーター）の発現抑制 やPAI（プラスミノーゲンーアクティベーターインヒ 

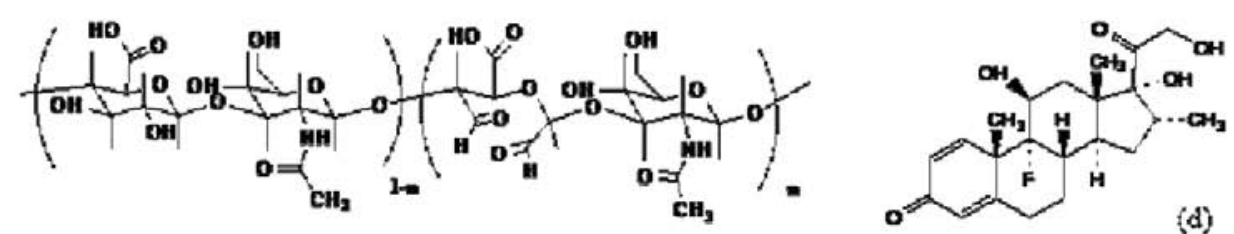

(b)
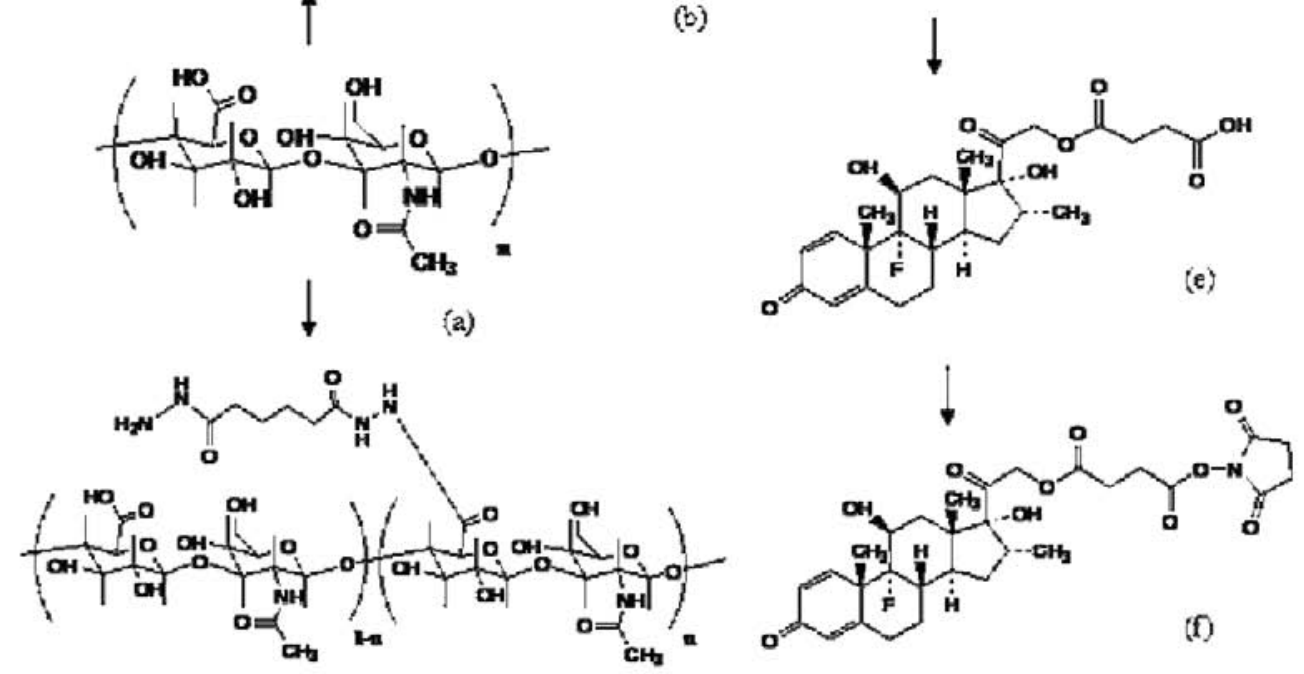

(c)

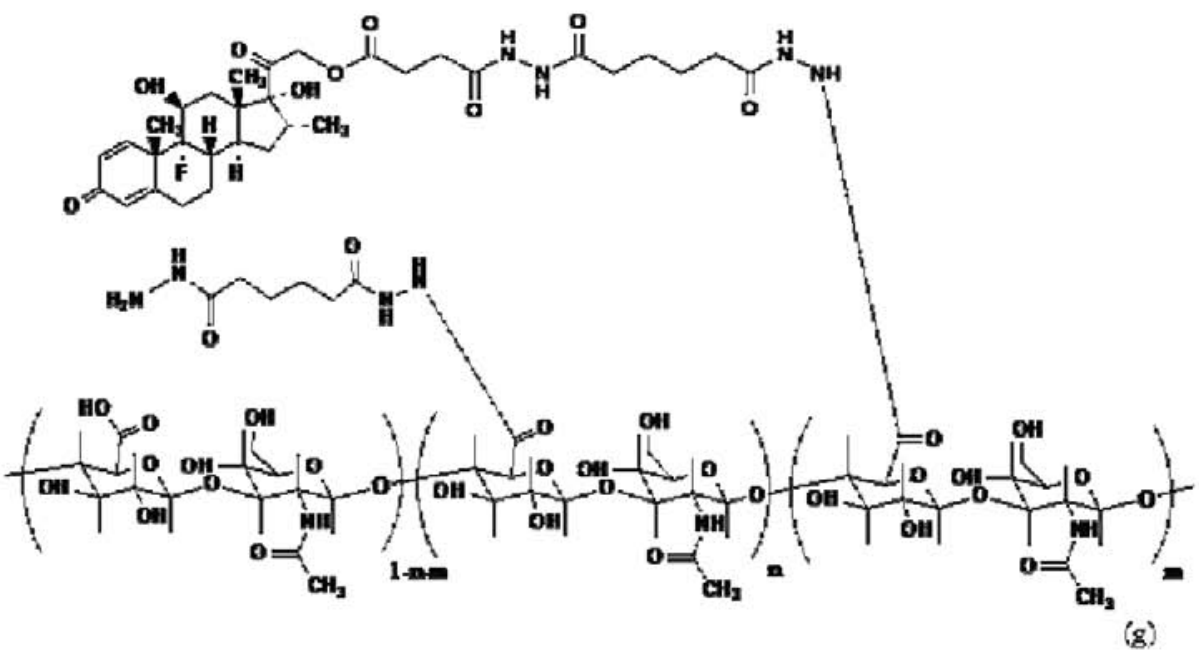

Fig. 5 Schematics of the synthesis procedures of hydrogel of hyaluronic acid and dexamethasone (HAX-DEX). (a)Hyaluronic acid (HA), (b)Aldehyde-modified hyaluronic acid (HA-ALD), (c)Adipic dihydrazide-modified hyaluronic acid (HA-ADH), (d)Dexamethasone, (e)Dexamethasone-succinate (dex-suc), (f) Synthesis of N-hydroxysuccinimide dexamethasone-succinate (NHS-dex-suc), (g)Hyaluronic acid-adipic dihydrazide-dexamethasone-succinate (HA-DEX). The hydrogel containing dexamethasone, HAX-DEX, forms by mixing (b)HA-ALD with (g)HA-DEX.

ビター）の発現六進を引き起こすことが報告されて いる ${ }^{12)}$ ．このためステロイド等の抗炎症薬のゲル薄 膜からの徐放を行うことによって，さらなる癒着低 減効果が期待できる. 我々は Fig. 5 に示すような合成 スキームによってデキサメタゾンをエステル結合に よって固定し，ハイドロゲル薄膜中からエステル結 合の加水分解によってステロイドが徐放されるよう なシステムを設計した ${ }^{13}$.
これらハイドロゲルを培地中でインキュベイショ ンして, 培地交換を $1,2,3,5,9$ 日後に行い, 得られた 培地を凍結保存した。 さらにマウス腹腔にLPS（リ ポポリサッカライド）を注入して腹膜炎状態にして 得られたプライマリーマクロファージを播種した後, これらの培地を添加することによって, 抗炎症効果 をTNF- $\alpha$ ，IL-6測定によって評価した. Fig. 6 に示 すように, デキサメタゾン担持ハイドロゲルが効果 


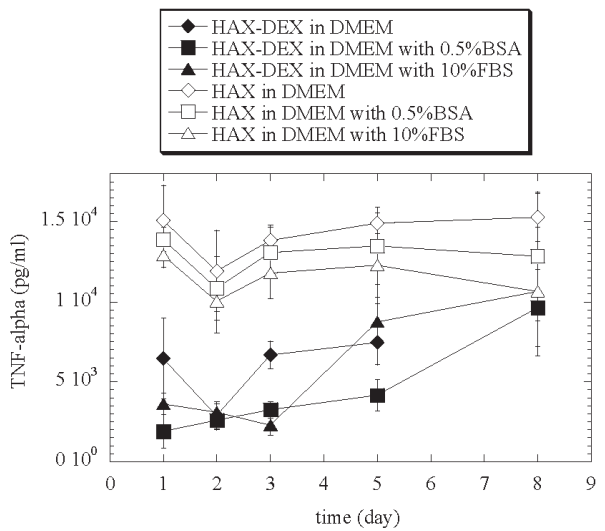

(a)

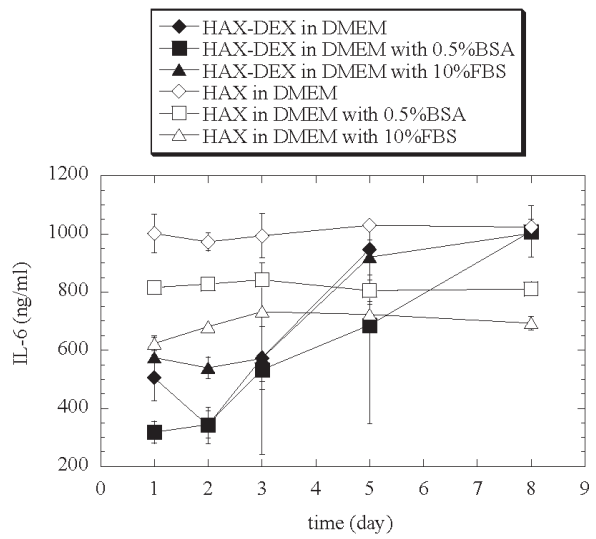

(b)

Fig. 6 The effect of dexamethasone on the production of $\mathrm{TNF}-\alpha$ and IL-6 from primary mouse macrophages.

的に炎症反応を抑制することを確認した。

\section{5. in situ架橋ハイドロゲルの架橋点間分子 量計算とタンパク質製剂の徐放}

剛性率とヤング率の関係はアフィン変形を仮定す る限り比例し，ヤング率へと換算できる。ささに Flory-Rehner-Peppasの式14) を用いて，含水率・ポ リマー濃度等から, 架橋点間分子量 : $\mathrm{M}_{\mathrm{c}}$ を推算する ことができる. Table 3 に結果を示すように，本研究 で作製したハイドロゲルの $\mathrm{M}_{\mathrm{c}}$ は $10 〜 200 \mathrm{kDa}$ と，か なり架橋密度が低いハイドロゲルであることがわか る. また計算結果から修飾したヒドラジド基やアル デヒド基の $1 \%$ 以下しか架橋に寄与していないことも わかる．このためさらなる混合架橋プロセスや分子 量の検討によって, より広範囲で架橋点間分子量を 制御することが可能であることが示唆される.

一方, 近年臨床分野で次々と臨床適用になってい る, タンパク質製剤の分子量は, 従来の低分子薬剤 に比べて非常に高い。例えば抗体は $25 \mathrm{kDa}, \mathrm{t}-\mathrm{PA} は$
Table 3 Estimation of the average molecular weight per crosslinking unit, Mc from swelling volume, $\mathrm{Q}$, and shear moduli, $\mathrm{G}$. ( $\mathrm{N}=4$, averages)

\begin{tabular}{|ccccccc|} 
& $W_{\text {initial }}$ & $W_{\text {swelled }} Q(-)$ & $\begin{array}{c}\text { Young's } \\
\text { modulus } \\
(\mathrm{Pa})\end{array}$ & $\begin{array}{c}\mathrm{G} \\
(\mathrm{Pa})\end{array}$ & $\begin{array}{c}\mathrm{Mc} \\
(\mathrm{kDa})\end{array}$ \\
\hline $\mathrm{HAX}$ & 318 & 395 & 2.37 & 97 & 32 & 71 \\
\hline $\mathrm{HA}-\mathrm{CMC}$ & 321 & 500 & 2.00 & 275 & 92 & 214 \\
\hline $\begin{array}{c}\mathrm{HA}- \\
\mathrm{HPMC}\end{array}$ & 345 & 366 & 1.35 & 875 & 292 & 14 \\
\hline HA-MC & 350 & 460 & 1.49 & 890 & 297 & 10 \\
\hline
\end{tabular}

$68 \mathrm{kDa}, \mathrm{IL}-2$ (インターロイキン 2) は $15 \mathrm{kDa}$ であ る. また再生医療で使用することが期待される細胞 増殖因子，例えばVEGF-A（血管内皮細胞増殖因子） は $38 \mathrm{kDa}$ である.

つまりこれらの遺伝子組み換えタンパク質製剂の 徐放を制御するには, 本研究のin situ架橋ゲルでも 十分な架橋密度であることもわかる. 実際にYeo ら ${ }^{15)}$ の結果では, 本ハイドロゲルを用いてアルブミ

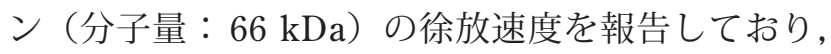
この系では拡散よりもハイドロゲルの分解により徐 放されることがわかる．これは八イドロゲル網目が 十分に細かく, タンパク質が中に封入されてしまっ た状態でほとんど拡散できない。一方でゲルの分解 とともに, 封入されたタンパク質製凨が放出されて いくことを示している.

\section{6. おわりに}

医用 in situ架橋ハイドロゲルと，生体内でのハイ ドロゲル薄膜形成について報告した. 現在二つの方 向に渡って研究を展開している。

一つは適用疾患の拡大と, 疾患に応じた材料設計 の研究である。例えば胃がんや卵巣がんは, 臓器漿 膜を破って腹腔中に拡散し, 腹膜や腹腔内臓器の漿 膜に広範囲に渡って転移し, 外科手術による根治が 不可能になる.これは腹膜播種 ${ }^{16)}$ と呼ばれる. 抗が ん剂療法により手術可能になるまで播種を低減でき れば, 現在の医療でほぼ治癒不可能な播種治療への 新たな道が開ける。しかしながらなかなか有効な抗 がん剤治療法が確立されず，ドラッグデリバリー技 術の進化が待たれるところであり, 主にシスプラチ ンを腹腔内投与に適用可能になるように研究を進め ている ${ }^{17 \sim 19)}$. ハイドロゲル薄膜内の薬物移動, 腹膜 中皮膜中の薬物移動などが鍵となってくる. また放 射線治療とインターロイキン製剤等の併用療法も, 
臨床では期待されており，これに向けて医用in situ 架橋ハイドロゲルによる局所徐放の最適化も期待さ れている．腹膜癒着防止材料も, Seprafilm等の臨床 適用材の適用範囲は限定されており, その癒着防止 効果も限界がある. 肝切除による新たな癒着動物モ デルの開発に成功しており ${ }^{20)}$ ，これをべースにして 新たな癒着防止材料の開発を進めているところで ある.

一方で, 新たな材料の開発は, 潜在的な医用二ー ズや医用プロセスを開発していく端緒となる．Fig. 1 で紹介した架橋プロセスの久点やゲル物性のトレー ドオフ関係をブレークスルーすべく，クリックケミ ストリーやグリコール核酸の二重らせん形成などの 新たな架橋反応を利用した医用in situ架橋八イドロ ゲルの開発に着手している。これらは将来的に再生 医療における 3 次元組織構築や, 新規 DDS 技術の開 発に寄与するものである.

これらの検討の中で, in situハイドロゲル薄膜は 明らかに膜である。すすおちDDSでは薄膜の中での 薬物移動が鍵である．再生医療では細胞の分化・増 殖・移動などが鍵になるが，様々な増殖因子が拡散 しあいながら相互作用をしてプロセスが進んでいく. 鍵は膜中での物質移動と反応であり, 分離膜・メン ブレンリアクター・生体膜の解析や開発などで培わ れてきた, 膜工学の蓄積, 応用, 進化なくして, 研 究や技術開発は行えないものである.

\section{謝 辞}

なお本研究はマサチューセッツ工科大学 Langer 教 授, ハーバード大学小児病院の Kohane准教授, パー デュウ大学のYeo 助教授らとの研究の賜物であり, ここに感謝します．現在共同研究を行っている，東 京大学医学部腫瘍外科 - 北山准教授, 石神講師, 山 口助教, 東京大学医学部肝胆膵外科・國土教授, 長 谷川准教授, 清水医師らに感謝致します。またヒア ルロン酸のご提供を頂いています（株）フードケミ ファ，ダブルシリンジをご提供頂きましたバクス ター（株）に感謝致します。

\section{文 献}

1) http://probes.invitrogen.com/media/pis/mp03000.pdf

2) Wang YC, Li Y, Yang XZ, Yuan YY, Yan LF, Wang J : Macromolecules, 42, 3026-3032 (2009)

3) Iwasaki Y, Wachiralarpphaithoon C, Akiyoshi K : Macromolecules, 40, 8136-8138 (2007)

4) http://www.kimica.jp/products/NaAlgin/

5) http://www.baxter.com/healthcare_professionals/products/tisseel.html

6) Shu XZ, Liu YC, Luo Y, Roberts MC, Prestwich GD
: Biomacromolecules, 3, 1304-1311 (2002)

7) Bulpitt P, Aeschlimann D : J. Biomed. Mater Res., 47,152169 (1999)

8) DiZerega GS : Peritoneal Surgery, Springer, New York (1999)

9) Yeo Y, Highley CB, Bellas E, Ito T, Marini R, Langer R, Kohane DS : Biomaterials, 27, 4698-4705 (2006)

10) Ito $T$, Yeo $Y$, Highley $C B$, Bellas E, Benitez CA, Kohane DS : Biomaterials, 6, 975-983 (2007)

11) Ito $T$, Yeo $Y$, Highley CB, Bellas E, Kohane DS : Biomaterials, 23, 3418-3426 (2007)

12) Oh SH, Kim JK, Song KS, Noh SM, Ghil SH, Yuk SH, Lee JH : J. Biomed. Mater Res., A72, 306-316 (2005)

13) Ito T, Fraser IP, Yeo Y, Highley CB, Bellas E, Kohane DS : Biomaterials, 10,1778-1786 (2007)

14) Peppas NA, Merrill EW : J. Appl. Polym. Sci., 21, 17631770 (1977)

15) Yeo Y, Bellas E, Highley CB, Langer R, Kohane DS : Biomaterials, 28, 3704-3713 (2007)

16) 米村 豊 : 腹膜播種, へるす出版 (1996)

17) 須原宜史, 鈴木幸光, 亀井隆雄, 山口博紀, 石神浩徳, 北山丈二，伊藤大知 : 日本膜学会，5月(2010), P30

18）須原宜史, 鈴木幸光, 亀井隆雄, 山口博紀, 石神浩徳, 北山丈二, 伊藤大知 : 化学工学会秋季大会, 9月 (2010), L209

19) 佐藤真優, 鈴木幸光, 伊藤大知 : 化学工学会秋季大会, 9 月 (2010), L204

20) 須原宜史, 佐藤真優, 鈴木幸光, 伊藤大知, 清水篤志, 成瀬勝俊, 長谷川潔, 國土典宏, 亀井隆雄, 石神浩徳, 山口幸二，北山丈二：材料化学システム工学討論会， 12 月 (2010)

(Received 8 December 2010; Accepted 11 January 2011)

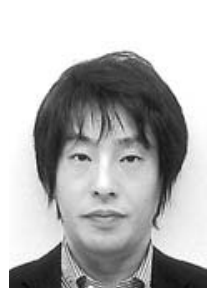

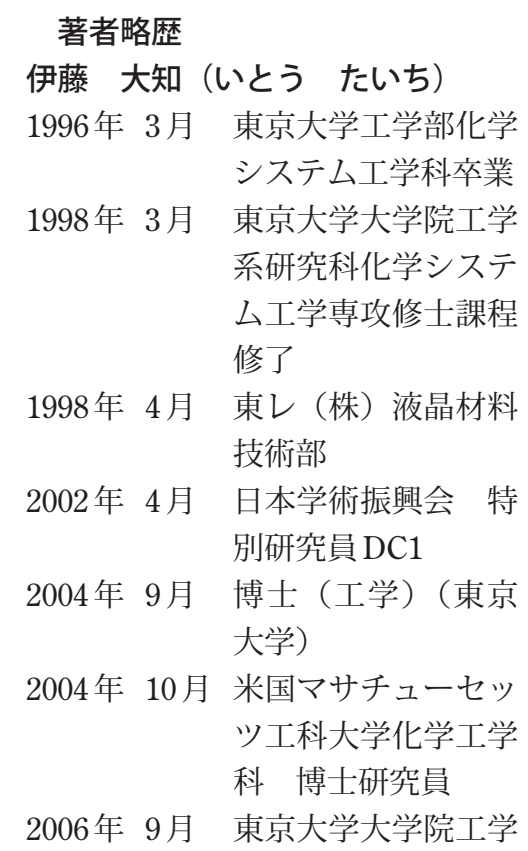


70 伊藤・鈴木 : 体内でのフィルム形成一腹膜癒着防止膜と薬物送達膜一

系研究科 助手

2007年 4 月 東京工業大学資源化 学研究所 助教

2009 年 2 月 東京大学大学院医学 系研究科附属疾患生 命工学センター 准 教授

2009年 4 月 東京大学大学院工学 系研究科化学システ 厶工学専攻 准教授 (兼担)

東京大学大学院工学 系研究科バイオエン ジニアリング工学専 攻 准教授（兼担）

鈴木 幸光（すずき ゆきみつ）

1998年 3 月 神奈川大学工学部応 用化学科卒業

2003 年 3 月 (工学) (神奈川大 学)

2003 年 4 月 科学技術振興事業団 さきがけ「合成と制 御」博士研究員

2004年 6 月 科学技術振興機構 CREST「高度情報 処理・通信の実現」 博士研究員

2006年 8 月 東京工業大学資源化 学研究所 研究員

2009 年 5 月 東京大学大学院工学 系研究科化学システ 厶工学専攻 特任 助教 